\title{
A Study of the Marketing Strategies of Estate Surveying Firms in Lagos, Nigeria
}

\author{
Ogedengbe Peter Shakede (Ph.D) \\ Edionwe Osasumwen
}

\author{
Department of Estate Management, University of Benin, Benin City, Nigeria \\ Email: psogedengbe@yahoo.com, peter.ogedengbe@uniben.edu
}

\author{
Doi:10.5901/ajis.2016.v5n1p81
}

\begin{abstract}
This study examines the marketing strategies that are being adopted by practicing firms of estate surveying and valuation in discharging their estate agency services in Lagos State. The objectives of the study include: examining the challenges that are associated with the present strategies being practiced by these firms with a view to providing solutions to them and examine ways of making estate agency more effective. A total of thirty-two practicing firms of estate surveying and valuation were examined in a survey conducted to elicit information on the strategies they adopt for marketing their services in the area of estate agency. Simple descriptive statistical methods were used for the analysis and presentation of the data. The result showed that some of these estate firms are facing problems in marketing the properties in their portfolio since they don't really have marketing skills that would have been provided, had there been a qualified marketer in their employment. The study recommended among others that estate firms should employ marketers in their firms or alternatively, the estate surveyors and valuers should go for some marketing courses in order to fine tune their marketing strategies.
\end{abstract}

Keywords: Marketing, Marketing strategies, services

\section{Introduction and Problem}

Estate surveying and valuation firms are concerned with the supervision and direction of an interest in land and landed properties on behalf of the owners of such interest with the aim of securing optimum return. This may not necessarily be pecuniary but can be in terms of prestige, political status, independence, and continuity, social and economic need to be satisfied.

These firms of estate surveyors and valuers are involved in various services to the public which basically border on land and landed property. These include sales of interest in land, lease of such interest, management of the interest, estimating the monetary worth of such interest at a particular point in time and for a particular purpose, feasibility and viability appraisals of land oriented ventures, and policy formulation, general consultancy on matters concerning land and landed properties etc.

Land is a free gift of nature but because all human activities rest and depend on land, the value can be said to be very high world over. In Nigeria for example, it is the desire of every man to own an interest in land and those who already have, want optimum returns from such interest.

The process of acquiring a piece of land and the ability to get the best in terms of return from the land calls for estate management which the estate surveyors and valuers are charged with. Land that is fixed in size and supply is competing with the ever increasing demand emanating from population explosion. In essence, the supply of land is not proportional to it demand, hence the need to balance the land oriented needs of the population and the available land in order to achieve highest and best use. This brought about the numerous estate surveying and valuation firms in the country today. Despite the number of these firms, they still strive very well in terms of profit from their services to the public even in the face of stiff competition among themselves.

The marketing strategies adopted by these firms are matters of concern to this research. This study intends to look at the following areas:

i. The marketing strategies the estate surveying and valuation firms adopt in Lagos for marketing their services

ii. The problems they face in adopting these marketing strategies

iii. How to improve upon the present strategies with a view to solving the problems associated with them 


\section{Operational Definition of Terms}

Marketing strategy is the sum total of all efforts used by estate surveying and valuation firms to attract business and to complete it successfully i.e. the firms' long term plans undertaken with a view to placing it in a competitive advantage over other firms in the real estate business.

\subsection{Concept of Marketing}

The concept of marketing varies from one researcher to the other but in the final analysis, there are certain things that are common to virtually all the perspectives as put forward by the various researchers.

Olufokunbi 1993 views marketing as the human activity directed at satisfying needs and wants through exchange process while also aspiring to achieve the marketer's objective. According to Kotler (1997), marketing is defined as 'a social and managerial process by which individuals and groups obtain what they need and want through creating offering and exchanging products of value with others'. This view is in line with the view of Olufokunbi (Op. cit). A departure from this perspective was put forward by Arndt(1978) who opined that for marketing to be a behavioral science, it must be finally based on positive theories providing a systematic explanation of the phenomenon of interest in this case, the economic need satisfaction process. He then concluded that while exchange may be fruitful abstraction of the marketing function, not all exchanges are marketing exchanges. Kotler (Op Cit) limits marketing to mean an exchange only, which implies that marketing, will cover only the revolving of the economic needs and wants in the society. In essence, it will not include exchanges in non-economic areas where participants are non-marketing institutions. This view is not acceptable to this research.

In his own view, Rosenberg (1977) defined marketing as "a matching process, based on goals and capabilities, by which a producer provides marketing. - mix (products, services, advertising, distribution, pricing etc) that meets consumer needs within the limits of the society". Stanton (1975) defined marketing as a total system of interacting business activities designed to plan, price, promote and distribute want-satisfying products and services to present and potential customers. He pointed out that the economic aspect of marketing includes consumer orientation, the dynamic nature of the marketing process and the marketing integrated form comprising interacting activities, designed to plan, price, promote and distribute want-satisfying products and services to present and potential customers.

Wilmshurst (1979) pointed out that consumption is the sole end and purpose of all production and the interest of the producer ought to be attended to, only as far as it may be necessary for promoting that of the consumer. Galbraith (1980) while trying to differentiate between marketing and selling opined that the difference between them is more than that of semantic, while selling is pre-occupied with the seller's need to convert his product into cash, marketing deals with the product and the whole cluster of things associated with creating delivering and finally consuming it.

Drucker (1973) is of the view that marketing is so basic that it cannot be considered a separate function but it is the whole business seen from the point of view of its final results, which is from the consumer's point of view.

Today's competitive market, demands that manager need to really understand the concept of marketing since it is a critical part of any business.

The American Marketing Association defines marketing as "the process of planning and executing the conception, pricing, promoting and distribution of ideas, goods and services to create exchanges that satisfy individual and organizational goals" Marketing is concerned with making decisions that revolve around how the goods or services of the organization can be made to match the customer's needs and wants (Czinkota and kotabe 2000)

Marketing is not just selling, although this is what many people think of when marketing is mentioned. If you want to be successful in the highly competitive market places of today, then you do not simply decide to make a product or supply a service and then market it. Marketing is not just the expenditure of vast sums of money on advertising campaigns and special offers in local super markets. Marketing is not only the junk mail that lands regularly on your door mat offering you all sorts of incentives to purchase that product. Marketing is not just research but marketing, in fact, is the whole set of activities which enable an organization to make decisions about what it will offer for sale, how much it will charge, who it will sell to and by what means it will make its offering available (Atkinson and Wilson 1996). They observe further that marketing is concerned with getting the right product or service to the right customer at the right price, at the right time and in the right place.

Marketing is the management process, which identifies, anticipates and supplies customer's requirements efficiently and profitably.

Marketing is a social process by which individuals and groups obtain what they need and want through creating, 
and exchanging, products and value with others.

Service firms appear to have generally less marketing mix activities being carried out in their marketing departments compared to the manufacturing firms. They hardly have an overall sales plan. The need for marketing strategy in any business is very crucial since firms require a well designed goal and direction which objectives alone can not achieve; hence there is need for additional decision rules for the firm to have orderly and profitable growth.

Marketing strategy includes selection of a target market and determination of the product, price, promotion and distribution policies that the firm will implement. The first step in target market selection is market segmentation while the second step is to select the segments on which the firm will focus its products, promotion, distribution efforts and at what price. Macro economic analysis determines the marketing strategy to be adopted as the one used during a period of boom may not be suitable in a period of depression or recession.

Marketing strategy can be defined as those activities associated with the anticipation and identification of clients' needs and desires, the development of tactics and strategies and the subsequent execution of these strategies to satisfy targeted clients' needs and desires. Marketing strategy is a constituent, appropriate and feasibility set of principles through which a particular company hopes to achieve its long run customer and profit objectives in a particular competitive environment (Kotler 1997, Alan and Thelma 1994).

Marketing strategy can generally be looked at as the manipulation of the four Ps (product, price, promotion and place) to the advantage of the firm concerned, i.e. how the four Ps can be utilized in order to achieve the organization's goal. The four Ps will be discussed below:

\subsection{Product strategy}

The economic setting of the world today calls for two different scenarios through the interaction of economic forces of demand and supply. It is either that demand exceeds supply or supply exceeds demand. In most cases, supply normally exceeds demand thereby leaving the faith of the manufacturer in the hand of consumers who choose to buy the product.

This is because there is competition among various and similar products. Quality has a role to play in the customer's choice of the product. On the part of the firm, the product decision will be in line with mass production in order to reduce cost, product packaging and branding to differentiate one's product from others in the market. The branding strategy to be adopted should be the one that suggests product benefits, product qualities, distinctiveness and be easily pronounced, recognized and remembered (Kotler op cit).

\subsection{Pricing strategy}

The pricing strategy to be adopted is normally determined by the overall goal of the firm and the firm's cost of production. A company could pursue six alternatives through its pricing strategy as identified by (Kotler Op cit):

i) Survival

ii) Maximisation of current profit

iii) Maximisation of current revenue

iv) Maximisation of sales growth

v) Maximisation of market skimming and

vi) Product quality leadership

The prevailing or current price of a product may have to change due to competition or acquisition of modern and improved technology, which reduce production cost. In addition, the motive of the company matters too, this may be either to penetrate the market or to maintain a status quo in terms of existing market share.

\subsection{Promotional Strategy}

The main promotional areas that are opened to a firm are personal selling, advertising, sales promotion and public relations. Firms should adopt a promotional mix policy such that cost of production will reduce, organization goal such as to increase market share or retention of a percentage share of the market will be achieved.

\subsection{Distribution strategy (place)}

In designing distribution channel, Kotler identified the following steps: analysis of the consumer needs for service output, 
establishment of the channel objectives, the identification of the major channel objectives, the identification of the major channel alternatives and lastly evaluation of the major channels selected.

Marketing channels and promotion strategy have been regarded as the most important factor influencing the development of promotion mix. The choice of strategy that will build up sales should be adopted. This strategy should focus on either push or pull strategy.

Push strategy is one where personal selling, sales promotions are directed to sales force and intermediaries in order to encourage them to sell your product, store and push through the channels. The producer uses push-money to motivate the intermediaries (e.g. Discount to retailers) to sell his product. In pull strategy, promotion activities will be directed towards the end users. In the case of consumer product, we use the pull strategy directed to the consumers and ask the customers to meet the retailer to request for the product hence the customers will pull the product along the channel.

Promotion mix is the blending of advertising, personal selling, sales promotion and public relations. Promotional objectives are to inform, persuade and remind. If advertising is not embarked upon, market share will be lost. After creating awareness, the customers need to be converted to adopters of the product. This can be achieved through the use of A.I.D.A Model which emphasizes that you should attempt to get the attention of the customer, stimulate his interest, arouse his desire for the product and obtain action which is the purchase of the product.

Marketing strategy in relation to estate agency by firms of estate surveying and valuation is the sum total of all efforts used to attract business and to complete it successfully through the satisfaction of clients and meeting firms corporate goal.

\subsection{Estate Agency}

Agency is a relationship, which exists when one party known as the principal appoints another party called the agent to represent him in his business transactions with other parties (Mohammed et al 200l, Joseph 2009, Sunday 2011).

Agency can also be viewed as a consensual relationship which arises when a person called the agent acts on behalf of another called the principal whereby the latter becomes answerable for the lawful acts the former does within the scope of his authority as they affect the legal relation between the principal and a third person. An estate agent is a person who is employed with or for the purpose of putting his employer (the principal) into legal relationship with the third parties.

The act to be done by an agent is of varying degree and nature. Thus, it may be the making of a contract, the institution of a legal action, or the assembly of a parcel of land where an agent enters into a contract on behalf of his principal; his conduct will produce two different results. Firstly, it will create reciprocal rights and liabilities between the two main parties, the principal and the third party. In other words, the contract thus entered into by the agent on behalf of this principal will have the same effects as if the latter has personally entered into the contract.

For the purpose of this work, estate agency is a kind of relationship where an estate surveyor acts as an agent to his client (the principal) and transacts land related businesses with a third party on behalf of his client.

That is a relationship whereby the estate surveyor and valuer acts as a middleman between a landlord and a tenant, buyer and seller of land and landed properties e.t.c This is a kind of arrangement whereby the estate surveyor and valuer acting as a middleman brings a willing seller and buyer of land and landed property into personal contact with a view to transacting a business.

\subsection{Creation of Agency}

Agency can be created through any of the following ways:

\subsection{By Agreement (Express or implied)}

It is essential to note that though no formality such as writing or deed is required for the valid appointment of an agent (which means an agent can be appointed orally) yet an old common law rule is that an agent to execute a formal document must be appointed by a deed. The commonest way in which agency relationship arises is by an express appointment of the agent by the principal. 


\subsection{Implied Appointment}

Implied authority may arise in two ways. One it may arise from express authority conferred. Thus in Ryan V Pilkington, the court held that an estate agent who was instructed to find a purchaser for a private hotel had an implied authority to accept deposit from the prospective buyer. Secondly an agreement to create agency may also be implied from the conducts of the parties.

\subsection{Agency by Estoppel}

It is a principle of law, which prevents a person from asserting the reverse of what he has previously represented, if another party has acted in reliance or that representation. In Saul Raccah. V. Standard Co of Nigeria Ltd., Watkins was employed to act as an agent for the defendant for the purpose of groundnuts. In September 192I, the agent was instructed not to purchase groundnuts from the plaintiff again. The agent refused and induced the plaintiff to purchase more tons of groundnuts. The defendant refused to pay. The court held that the plaintiff honestly believed that the agent still retained the authority of the defendant and the defendant must pay.

\subsection{Agency by Ratification}

Agency may be created by ratification where A purports to act as agent for B either having no authority at all or having no authority to do that particular act, the subsequent adoption by $B$ of As act has the same legal consequences as if $B$ had originally authorized the act. But there can be no ratification unless $A$ purported to act as agent and to act for $B$ and in such a case alone can ratify. Ratification is retroactive, it relates back to the time of transaction and not to the time of ratification.

\subsection{Agency by Operation of Law}

This arises in an emergency condition; it is essential to act in order to prevent irreparable loss. It may arise where parties have an existing contractual relationship. In the case of Lagan v. Great Western Railway Co. a railway police inspector took an injured passenger in a railway collision to an inn. He was held to be an agent of necessity of the Railway Company to such an extent as to bind the company for board and lodging supplied to the injured passenger.

Another agency that can arise can arise by the operation of law is agency by cohabitation where a husband and wife live together or where a man and woman live together (whether married or unmarried) the wife or the woman has authority to pledge the husband or the man's credit for necessaries suitable to the style in which they live.

\subsection{Services rendered by the firms}

The following services were discovered to be rendered by the practising firms of estate surveying and valuation

\subsection{Valuation for various purposes}

This is the art and science of estimating the monetary worth of an interest in land and landed property at a particular point in time and for a particular purpose. That is, these firms estimate the monetary worth of land and landed properties for various purposes. For example a man that wants to obtain a loan from the bank will be required to set aside collateral security in form of land and landed property for the bank to be able to sell it and recoup its money in case the borrower defaults in payments. It is the Estate surveyor and valuer that will be called upon to ascribe monetary value to the property that was set aside so as to determine how much the bank should advance as loan.

Another purpose of valuation is insurance where the estate surveyor and valuer estimates the monetary worth of the property against any peril. This helps the insurer to know how much he will be paying at regular intervals as premium and how much the insurance company will pay to the person that insured his property with them in case of any eventuality such as fire.

As a result of development, Government may decide to widen or dualise a particular road, in which case some houses and farm crops may have to be destroyed before such road project can be embarked upon. The estate surveyor and valuer values these properties so as to know how much the government should pay as compensation to the 
claimants. This can also be in form of oil spillage where owners of affected properties need to be compensated by the oil company.

A company may call on an estate surveyor and valuer to value it assets for balance sheet purposes or to know the going concern value. In the alternative, the valuation may be for gone concern in which case, to know the worth of the company's assets when it folds up or when an alternative use is being contemplated. In the process of privatization; The estate surveyor and valuer is equally useful in order to know how much the company or parastatal should be exchanged for.(Enever 1989)

\subsection{Agency}

This is an area where the estate surveyor and valuer acts as a middleman between two people e.g. Landlord and tenant, seller and buyer of land and landed property. The estate surveyor and valuer is the best person to be called upon when one needs accommodation to let in case one had just been transferred to a place and the person has no accommodation. Here the estate surveyor and valuer brings the prospective tenant in contact with the accommodation he wants thereby striking a deal between the landlord and the tenant. In either way, the tenant is satisfied having gotten what he wants in terms of accommodation and the landlord is satisfied too having gotten his rent from the tenant A landlord may wish to sell his property and someone may want to buy such property also, the estate surveyor and valuer tries to bring these two people together so that the property can be sold and bought.

\subsection{Management}

Here the estate surveyor and valuer helps landlords to manage their land and landed properties. The estate surveyor and valuer helps to select suitable tenants into the property, collects their rents and remit same to the property owner. In case of defects in the property, he helps to effect repairs on behalf of the landlord if it is the landlord's responsibility.

\subsection{Feasibility and viability appraisal}

The estate surveyor and valuer helps to determine how feasible and viable a proposed investment in landed property would be and advises accordingly what the client should do (Richmond 1985).

\subsection{Land policies formulation}

All policies relating to land are usually formulated by land experts such as an estate surveyor and valuer. Example of such land policies are the land use Act No 6 of 1978, The National housing policy of 1991, Rent control Edict of various states e.t.c. Others are New town development like Abuja, urban renewal and slum clearance like maroko etc.

\section{Research Methodology and Findings of the Survey}

All the practicing firms of estate surveying and valuation in Ikeja Lagos state have been adopted as the sample size

These firms are 32 in number as obtained from the directory of the Nigerian institution of Estate surveyors and valuers. This system was adopted since Ikeja serves as the case study. Thirty-two questionnaires were administered out of which thirty were correctly filled and returned, these form the basis of the analysis below:

Table 1: Getting of briefs from clients

\begin{tabular}{|l|c|c|}
\hline Means & Responses & \% response \\
\hline Letter of proposal & 4 & 13.35 \\
\hline Scouting & 16 & 53.3 \\
\hline Goodwill & 7 & 23.35 \\
\hline Personal contact & 3 & 10 \\
\hline Total & 30 & 100 \\
\hline
\end{tabular}

Source: Field survey. 
From table 1 above, it can be seen that 53.3 percent of the respondents claimed that they get their briefs from clients through scouting, 23.35 percent of the respondents believe that their briefs from clients are normally based on the goodwill of the firm which it has built over the years. 13.35per cent supported the fact that the briefs they get from clients are normally through letter of proposal, which they wrote to the clients while the remaining 10 percent of the respondents get their briefs from their clients through personal contact with them.

It can be noted that briefs generally come to the estate surveying and valuation firms through scouting for these properties by them.

Table 2: Regularity of briefs

\begin{tabular}{|l|c|c|}
\hline Rate & Responses & \% Response \\
\hline Very regular & 16 & 53.3 \\
\hline Regular & 7 & 23.35 \\
\hline Not regular & 7 & 23.35 \\
\hline Total & 30 & 100 \\
\hline
\end{tabular}

Source: Field survey.

The above table shows that 53.3 percent of the respondents agree that the briefs they get are very regular. This percentage contrasts the percentage that gets briefs through scouting hence they believe that getting briefs was not regular. Those who get their briefs as a result of the good will they have built over the years believe that briefs are regular from clients. This forms 23.35 percent while the remaining 23.35percent believe that the rate at which briefs are got is not regular. These are the group who get briefs through personal contact and letter of proposal.

Table 3: Method of sales by the firms

\begin{tabular}{|l|c|c|}
\hline Method & No of responses & \% Responses \\
\hline Auction & 3 & 10 \\
\hline Tender & 5 & 17 \\
\hline Private treaty & 22 & 73 \\
\hline Total & 30 & 100 \\
\hline
\end{tabular}

Source: Field survey.

The above table shows that 73 percent of the firms use private treaty for the sales of land and landed properties in their portfolio; 17 percent of the firms engage in tender in selling their properties while 10 percent use auction sales in disposing of properties in their portfolio.

Majority of the estate firms contacted sell the properties in their portfolio by private treaty.

Table 4: Marketing of real estate services

\begin{tabular}{|l|c|c|}
\hline Promotional-mix & No of Responses & \% Response \\
\hline Personal Selling & 17 & 56.7 \\
\hline Advertising & 7 & 23.3 \\
\hline Public Relations & 5 & 16.7 \\
\hline Others & 1 & 3.3 \\
\hline
\end{tabular}

Source: Field survey.

The above table shows how the various estate surveying and valuation firms market their services through the promotional - mix.

Out of the total number of firms contacted, 56.7 percent of them adopt personal selling as a promotional strategy of getting in touch with their clients and the general public, 23.3 percent of the respondents adopt advertising as a means of getting the attention of the public, while 16.7 percent of them use public relations but the remaining 3.3 percent of the 
total respondents use sales promotion. This sales promotion is not popular among the estate surveying and valuation firms since they don't manufacture goods but render services.

Table 5: Problems of marketing real estate services.

\begin{tabular}{|l|c|c|}
\hline Problems & No of responses & $\%$ Response \\
\hline Multiple agencies & 12 & 40 \\
\hline Difficult clients & 10 & 33.3 \\
\hline Quacks & 5 & 16.7 \\
\hline Government legislation & 3 & 10 \\
\hline Total & 30 & 100 \\
\hline
\end{tabular}

Source: Field survey.

Problem of multiple agencies is rated very high out of all the problems the estate surveying and valuation firms encounter in marketing their services. This takes about 40 percent while difficult clients rated second with about 33.3 percent of the total respondents. The remaining 16.7 and 10.0 percentages represent problems of quacks and government legislations respectively.

Table 6: Problems affecting the real estate market

\begin{tabular}{|l|c|c|}
\hline Problems & No of responses & \% Response \\
\hline No central market & 6 & 20 \\
\hline Large Capital & 7 & 23.3 \\
\hline Economy & 15 & 50 \\
\hline Others & 2 & 6.7 \\
\hline \hline Total & 30 & 100 \\
\hline
\end{tabular}

Source: Field survey.

Economy rates highest out of the various factors affecting the real estate market, this shows that, when the economy sneezes, it is the property market that catches the cold. If the economy booms, the property market will be vibrant and vice versa. Other factors that affect the property market include lack of central market, large capital outlay needed to participate in the market and others like indivisibility of landed properties e.t.c. From the above table, economy takes 50 percent as a factor that affects the real estate market. Lack of central market takes 20 percent, large capital outlay takes 23.3 percent, while others take 6.7 percent

Table 7: Promotional strategies adopted by the firms

\begin{tabular}{|l|c|c|}
\hline Strategy & No of responses & \% Response \\
\hline Product differentiation & 2 & 6.7 \\
\hline Discount & 3 & 10 \\
\hline Public Relations & 5 & 16.7 \\
\hline Staff Motivation & 5 & 16.7 \\
\hline Promotion & 2 & 6.7 \\
\hline Advertising & 8 & 26.6 \\
\hline Personal Selling & 5 & 16.7 \\
\hline Total & 30 & 100 \\
\hline
\end{tabular}

Source: Field Survey.

Most of the estate surveying and valuation firms use advertising as a promotional strategy to reach out to the public in promoting and marketing their services. Staff motivation is rated equally with public relations, and personal selling; some of the firms motivate their staff by giving them incentives in order to improve output in terms of marketability. A public relation is carried out by the firms by giving clients some material reward during celebrations like Christmas. Product 
differentiation is low among estate surveying and valuation firms since they are not into manufacturing.

Their charges for services rendered are dictated by the federal Government scale of professional charges hence discount is not usually adopted by the firms but a few still adopt it.

Table 8: Problems of marketing strategies

\begin{tabular}{|l|c|c|}
\hline Strategic area of problem & No of responses & \% Response \\
\hline Product & 3 & 10 \\
\hline Price & 2 & 6.6 \\
\hline Promotion & 20 & 66.7 \\
\hline Distribution & 5 & 16.7 \\
\hline Total & 30 & 100 \\
\hline
\end{tabular}

Source: Field Survey.

From table 8 above, it is obvious that the major problem the firms face is in the area of promoting and marketing their goods and services in terms of advertising. This rates as high as 66.7 percent while, the problem they face in terms of distributing their goods and services is relatively high. This takes about 16.7percent. The area of product manufacturing which is viewed in terms of acquiring some properties in their portfolio through scouting for either management or outright sales. The problem they face in this area of acquisition takes 10 percent, while problem with the pricing on the product or services takes 6.6 percent. This is relatively low since the charges are already stipulated by the federal government scale of professional charges.

The major reason why promotional problem is so high among them is that they lack marketing skills and expertise hence the advertising they go into does not yield the desired result.

Table 9: Need for a qualified marketer.

\begin{tabular}{|l|c|c|}
\hline Marketer & No of responses & \% Response \\
\hline Yes & 21 & 70 \\
\hline No & 9 & 30 \\
\hline Total & 30 & 100 \\
\hline
\end{tabular}

Source: Field survey.

Out of the total respondents, 70 percent of them believed that there was need for a qualified marketer to be in the employ of the firm in marketing its services which is virtually the most vital aspect of the firm's dealings, while 30 percent of the respondents believed otherwise.

\section{Interpretation}

The study revealed that the practising firms of estate surveying and valuation that embarked on advertising mostly did that when sales is going down and they were into product advertising which focuses majorly on their products (i.e. properties in their portfolio). If an estate firm has a duplex for sale, the major things they advertise will be the available property which to the researcher is myopic compared to institutional advertising that focuses on the image of the firm. If this institutional advertising is effective, it gives blanket coverage to all the products and services of this firm. In essence, the company or firm can introduce any new product or service in the market without spending much since such service is already enjoying blanket coverage being from the firm. The resultant effect of the product advertising that these firms embarked upon is lack of image for the firms. Without this image, customers or clients tend to forget about the firm and will not be motivated to want to transact business with it. As a result of this advertising they go into, the objectives of advertising which are to inform the target audience, to persuade them and to remind them are hardly achieved.

As pointed out earlier on, these firms only advertise when there is decline in the sales of their products or services but when sales picks up, they stop advertising which shows lack of consistency resulting to lack of proper information processing on the part of the target audience about the firm, hence they forget easily about such firm.

It was discovered that most of these estate firms do not have qualified marketers in their employ, hence the 
adverts they place, which are mainly in the print media are always done without expertise but on trial and error basis. There is no creativity in these adverts. These adverts in the print media are normally short lived since readers hardly keep it around them for more than a day. The desired result is seldom achieved. For their advertising to be effective, they should utilize broadcast media such as television and radio, which are not too popular among the estate firms.

If an estate firm has a property it wants to sell or let, It will place a "For sale" or "To let" board on such property with its contact address and phone number for further information about the property. The implication of this is that only those who see the property will be able to enquire about it. This stresses the importance of advertising. They are more into personal selling which is not so effective.

It was also revealed that these estate firms do not give motivation of staff the priority it deserves. This explains why the few ones that motivate their staff perform better than others who feel otherwise. Discount pricing as a stately was not used by the estate firms since they have scale of professional charges as stipulated by the federal government. They do not embark on promotional strategy since they don't manufacture any product.

Some of the few estate firms that are really doing well in the field adopt some of these marketing strategies which others don't.

\section{Conclusion}

The Study has been able to show the importance of a qualified marketer in the affairs of practicing firms of estate surveying and valuation, which means that their level of market share and profitability can be improved upon.

Marketing is very crucial to the survival of any business concern since its input is required for the deal to be completed. Some of the estate firms hardly advertise because of the high cost of advertising which unknown to them will bring about high profitability that will make them to remain in business for a long time.

Estate surveying and valuation firms should realize the importance of each of these components of the promotion mix (personal selling, advertising, sales promotion and public relations) to the survival of their firms and fine-tune their marketing strategies accordingly. Social responsibility is one area that most of these firms have ignored hence they are not visible in their areas of operation.

\section{Recommendations}

The estate surveying and valuation that wants to be leading in the property market should establish a marketing department that will fine tune their existing strategies that are not too effective. A qualified marketer can be employed permanently in such firms to accelerate this positive improvement or in the alternative; estate surveyors and valuers should go for some marketing courses which will be beneficial in both long run and short run to the firm.

In case of placing an advert in print or broadcast media, the marketer will use his professional expertise to make such advert effective by achieving promotional objectives.

Marketing both the products and services of estate surveying and valuation firms should attract as much importance as that of getting briefs and clients. Estate surveyors and valuers tend to give more attention to sourcing for briefs or properties than the final disposal of such properties or execution of the briefs hence some properties for sale spend so many; years in the property portfolio of such firms without getting a buyer.

Estate firms should try and draw up marketing plans that will be strategic enough for corporate objective to be achieved. This can be made possible through the help of a marketer.

They should embrace institutional advertising instead of product advertising since the former creates blanket coverage for all the firm's products as a result of projection of the firm's corporate image. These firms should perform some social responsibilities to the communities where they are located so as to improve their visibility.

\section{References}

Alan. H. and Thelma D. (1994): Effective marketing: A skills and activity based approach. Oxford Blackwell.

Arndt. J (1978) How broad should the marketing concept be? Journal of Marketing January 1978 Vol 2 No 2.

Atkinson. J. and Wilson. I. (1996): Strategic Marketing: cases, concepts and challenges. Harper Collins London.

Czinkota R.M.and Kotabe M.(2000): Marketing Management $2^{\text {nd }}$ ed South Western College publishing. Australia.

Drucker. F.P. (1973) Management;Tasks and Responsibilities Practices. New York Harper and Row.

Enever. N. (1989): The valuation of property investments. The estate Gazette Ltd., London.

Galbraith K.J (1980): Marketing concept. Macmillan press 
Joseph G (2009): Understanding Commercial Real Estate: Just How Different from Housing is it? National Bureau of Economic Research, Working Paper 14708.

Kotler. P. (1997): Marketing Management: Analysis, Planning, Implementation and control $9^{\text {th }}$ Edition Prentice Hall.

Mohammed, J. Osuntogun, A. and Adeyombo A. (2001): General principles of law for business management. Gavima press limited Ibadan, Nigeria.

Olufokunbi B. (1993): Marketing and successful living Inaugural lecture series, Obafemi Awolowo University, Ile-Ife.

Richmond. D,. (1985): Principles of valuation, Macmillan press London.

Rosenberg L.(1977): Marketing. Eaglewood cliffs, Prentice - Hall.

Stanton W.J. (1975): Fundamentals of marketing Mc GrandHill Tokyo.

Sunday O. (2011): Residential Real Estate Properties in Nigeria: How Fair Are the Market Prices? JORIN 9 (2) www.transcampus.org., www.ajol.info/journal/jourind.

Wilmshurst. J. (1979): The fundamental and practice of marketing Heinemann London. 
